\title{
Protection of Rare Plant Species during the Development of Oil Fields in the South of Western Siberia (Tyumen Region, Russia)
}

\author{
Valerii Glazunov* \\ Tyumen Scientific Centre SB RAS, Institute of the problems of Northern development, 2774, \\ Tyumen, 625003, Russia
}

\begin{abstract}
The article provides a description of the vegetation and information on the discovery of plant species subject to protection, as revealed during the examination of the territory of licensed oil production sites located in the Uvatsky district of the Tyumen region (Western Siberia). The vegetation cover of the territory is represented by a combination of plots of dark-coniferous grass-shrub-green-moss forests, derivative communities in their place, pine-shrub-sphagnum marshes and floodplain meadow-shrub vegetation. The localities of 7 rare species subject to protection at the state and regional levels were discovered, including 2 species of lycopods (Isoetes lacustris, I. echinospora), 2 species of ferns (Dryopteris filix-mas, Phegopteris connectilis), 1 species of angiosperms (Nuphar pumila), mosses (Neckera pennata) and lichens (Lobaria pulmonaria). To preserve the discovered habitats of protected species, the necessary changes were made to the layout of the oil production facilities.
\end{abstract}

In accordance with Article 35 of the Law of the Russian Federation "On Environmental Protection" (No. 7-FZ), when positioning industrial facilities, compliance with environmental safety requirements must be ensured, taking into account the consequences of operating these facilities and observing the priority of maintaining a favorable environment, biological diversity, and the rational use and reproduction of natural resources. Information on the presence of rare species subject to protection on the territory is an obligatory part of projects for the development of deposits, the construction of transport and other communications, and the development of environmental measures.

Several licensed oil production sites located in the western part of the Uvatsky district (Nelymsky, Zapadno-Nyurymsky, Demyansky, Shalimovsky) are currently being developed and launched into commercial operation by PJSC Surgutneftegas. In 2016 and 2018 The Institute of the problems of Northern development carried out an ecological and biological examination of the territory in the proposed locations of 9 quarries for the extraction of sand, part of which were floristic and geobotanical studies, as well as an assessment of the presence or absence of plant species subject to protection.

\footnotetext{
*Corresponding author: v_gl@inbox.ru
} 
Oil fields located within the boundaries of the district are relatively small and difficult for production; due to this, their commercial development only began in 1992. Floristically, the Uvatsky district remains one of the most poorly studied districts in the south of the Tyumen region. Basic information about the flora of this territory was obtained during the preparation of the dissertation by N. Drachyov [1] and is contained in a number of publications [2-4]. Later on, the data collected by N. Drachyov and other authors was summarized in the "Guide to Vascular Plants of the Tyumen Region" [5]. Information about rare plant species subject to protection was used in the preparation of the $2^{\text {nd }}$ edition of the Red Data Book of the Tyumen Region, which is scheduled for release in 2019. The main list of species to be introduced into the Red Data Book of the Tyumen Region (according to the Resolution of the regional government No. 590-p dated 29.11.2017, which is currently in force), includes 140 species of vascular plants (127 species of angiosperms, 9 - ferns, 4 - lycopods), 10 species of bryophytes and 3 species of lichens.

The main part of the Uvatsky district (an area of more than 48 thousand $\mathrm{km}^{2}$ ) is located within the Ob-Irtysh watershed. In terms of geobotanical zoning, the plots of the planned quarries under consideration are located within the middle taiga (in the zone of contact with the southern taiga subzone) of the forest latitudinal zone of the West Siberian Plain [1]. The middle taiga subzone is characterized by the predominance of dark-coniferous and pine forests and derivative communities in their place. The southern strip of the middle taiga is characterized by spruce-cedar with silver fir and small-grass-lingonberry-green-moss forests. Dark-coniferous (cedar, sliver-fir-spruce and silver fir) forests and mixed forests with varying degrees of participation of small-leaved species are represented in the drained sections of the interfluves. The vegetation of the floodplain of the Irtysh River in this segment belongs to the subtaiga type and is represented mainly by rows of meadow communities. Here, at the high levels of the riverine sections of the floodplains, willowbirch and birch-aspen forest communities develop.

Most of the dark-coniferous forests have a derivative origin and constitute various stages of post-fire successions. This leads to a complex composition of growing stock, in which, in addition to dark-coniferous species present in various combinations, small-leaved species (Betula pubescens, Populus tremula), and sometimes Pinus sylvestris, are also found.

The dark-coniferous forests of upland habitats in the area under consideration belong mainly to the green-moss group of forest types (small-grass-green-moss, shrub-green-moss and others). Forests of this group are characterized by high productivity indicators (yield class III - IV) and the fullness of tree stands. The upper tree tier has a height of 18-20 m; the average trunk diameter is $20 \mathrm{~cm}$. Shrub undergrowth is mild. There are single specimens of Sorbus sibirica, 2-4 m high, of Rosa acicularis, and of Rubus melanolasius. The underwood is of medium density, uniform, and represented by dark-coniferous species that are forest formers: spruce, cedar and silver fir. The ground cover has a mosaic distribution, and is quite diverse. The projective coverage of the grass-shrub tier is $60-80 \%$. Vaccinium vitis-idaea, V. myrtillus, and Linnaea borealis prevail in it. Equisetum sylvaticum, Carex macroura and C. globularis are found in considerable abundance. The group of taiga small grasses is widely represented - Oxalis acetosella, Trientalis europaea, Maianthemum bifolium, Orthilia secunda, Pyrola rotundifolia and others are present. The moss cover is at $30-60 \%$, and contains various types of forest green mosses. Pleurozium schreberi predominates. Microdepressions are sometimes occupied by sphagnum mosses. The species richness of the lower tiers in forests of this type averages 20-25 plant species. Within the area of study, actual dark-coniferous forests in the form of separate masses are practically not represented and are found only in the form of small fragments of the derivatives of dark-coniferous-small-leaved forests - birches and aspens are constantly present to some extent in the tree stand composition. 
Derived birch and aspen forests in the area of study are represented by the same forest types as zonal dark-coniferous forests, which determines the similarity in the structure of the lower tiers of the forests and the composition of the dominants. Favorable lighting conditions under the crowns of the hardwoods contributes to the intensive development of a living ground cover (90-100 \% coverage) and the formation of a high species richness (3035 species).

Secondary forests with a predominance of Populus tremula are very characteristic of the reforestation process in the southern taiga and the adjacent strip of the middle taiga [1]. The soils of these forests are distinguished by increased trophicity, which is especially characteristic of valley habitats (high floodplain terraces). The tree tier of such forests consists of Populus tremula with Betula pubescens and dark-coniferous species. Occasionally, Pinus sylvestris is present. The crown density and fullness are high (0.7-0.8). The basis of the tree tier is formed by Populus tremula and Betula pubescens 20-22 m high at the age of 70-90 years. There are a few rare old trees, Pinus sibirica and Abies sibiricathe remnants of the former pre-fire forest. An underwood of dark-coniferous species, mainly Abies sibirica and Picea obovata, forms the lower tier of the tree stand. In the underwood, different-aged generations from seedlings to specimens of 60-70 years old, forming an independent tier, are found. Abies sibirica is often represented by a creeping form. An undergrowth of Betula pubescens always develops in similar plantings, but when conifers are well developed, it is often substantially inhibited. Padus avium and Rubus melanolasius are found in the undergrowth along with shrubs common to the southern taiga forests - Rosa acicularis and Lonicera pallasii. The grass-shrub tier is well developed, has a projective cover of $80-90 \%$, and is heterogeneous in structure. Of the shrubs, Vaccinium vitis-idaea, V. myrtillus and Linnaea borealis are present. Species of taiga small grass and/or broad and tall grass (Aconitum septentrionale, Thalictrum minus, Athyrium filiixfemina and Dryopteris carthusiana) with the constant participation of Carex macroura and Calamagrostis obtusata usually predominate in the grass cover. The moss cover is up to $80 \%$ and is represented by green mosses.

In the depressions of the terrain, small areas of boggy dark-coniferous-birch with pine, sedge- and cotton-grass-shrub-sphagnum forests, with the participation of Carex vesicaria, Carex globularis, Calla palustris, Vaccinium myrtillus, Ledum palustre and Oxycoccus palustris, develop.

Due to its high ecological plasticity, Pinus silvestris is widespread in various types of habitats. Inner bog pine forests with a shrub-sphagnum cover are single-tier, low-yield class and floristically poor. In the tree stand, in addition to Pinus sylvestris, individual trees of Pinus sibirica and Betula pubescens can also be found. The height of the tree stand is $4-8$ meters, the average trunk diameter is $6-8 \mathrm{~cm}$, and its fullness varies from $0.6-0.7$ inside the mass to $0.3-0.4$ at the border with the swamps. Undergrowth is usually absent. The ground cover is continuous with a total projective coverage of up to $100 \%$. In the upper tier, Ledum palustre or Chamaedaphne calyculata dominate. Of the grasses, Carex globularis is most widely represented, and Eriphorum vaginatum is less common. The moss cover is formed by sphagnum mosses (Sphagnum fuscum). Sometimes lichen spots (Cladonia sylvatica and Cl. Rangiferina) are found. The total species richness of the lower tiers of the forest in different areas ranges from 5 to 12 species.

Large areas of the middle taiga are occupied by upper sphagnum bogs, with the participation (in various marsh forms) of Pinus sylvestris, 1.5-3 m high. The vegetation of bogs of this type is rather poor and repetitive. In places, the hummock-ridge complex structure can be fairly well traced. Ledum palustre and Chamaedaphne calyculata, which are present in various combinations, dominate in the grass-shrub cover of mounds and ridges. Common species also include Andromeda polifolia, Oxycoccus palustris and Vaccinium vitis-idaea. Eriophorum vaginatum, Carex limosa and Drosera rotundifolia are 
common in the depressions. In total, the species richness of grassy vegetation in different areas ranges from 5 to 10 species. The moss cover of ridges and depressions is formed by sphagnum mosses. The central parts of the deepest depressions are flooded.

Pine-shrub-sphagnum oligotrophic bogs are usually represented by small areas covered by a mass of trees or occupy relatively extensive areas on large bog systems, where they are located on the most drained slopes and on stripes around lakes and islands of forest. The tree tier is formed by pines of small height (2-4(6) m). A shrub layer consisting of Ledum palustre and Chamaedaphne calyculata is well developed. In the depressions between the hummocks, low shrubs (Oxycoccus palustris and Andromeda polifolia) are found. The grass cover is mainly represented by Rubus chamaemorus; in some places Carex globularis and Eriophorum vaginatum develop, forming hummocks. Drosera rotundifolia is found. Sphagnum mosses (Sphagnum angustifolium, Sph. magellanicum and Sph. fuscum) predominate in the moss cover.

The vegetation of the vast floodplain of the river Irtysh is represented by communities of meadow, shrub, and woodland vegetation, diverse in composition and structure. According to their dynamic properties, most of the floodplain plant communities belong to the serial category, the existence of which is conditioned by the extreme instability of the habitats associated with the constant variability of the hydrological regime. According to its structural features, the Irtysh floodplain belongs to the ridged-segmented type. It constitutes an alternation of ridges and depressions that were once river channels, usually forming a complex fan-shaped pattern. The flood regime of the river and the relative height of the elements of the floodplain terrain have a decisive influence on the differentiation of the vegetation cover. Depending on this, sections of low, medium (composed of medium-low and medium-high) and high ecological levels are distinguished in this part of the Irtysh floodplain, varying in the different durations of flooding by flood waters [1].

Most often flooded are low-level surfaces, i.e. inter-ridge depressions, young coastal shoals, old river beds and floodplain lakes. They have a height of up to $5 \mathrm{~m}$ relative to the low-water level and are flooded annually for a period of 1.5 to 3 months. The dominant position in their vegetation cover belongs to swampy sedge (mainly from Carex acuta), sedge-canary grass and canary grass (Phalaroides arundinacea) meadows, areas of willow coppices (Salix dasyclados) and grassy bogs, mainly consisting of rush and reed grass. In the area of study, sedge meadows made up of Carex acuta with an admixture of Carex vesicaria and Carex juncella and the participation of Galium uliginosum and Ranunculus lingua predominate, alternating with sections of willows represented by Salix cinerea.

Middle-level sites occupy most of the slopes of high and medium ridges. They are located in the range of relative heights of 5-8 m, and are flooded annually or every 2-4 years for $0.5-1.5$ months. These areas are dominated by polydominant grassy-gramineuos and gramineous-grassy meadows, rich in composition, alternating with thickets of shrub willows (Salix cinerea, S. pentandra and S. rosmarinifolia).

High-level areas (above $8 \mathrm{~m}$ ) are rarely flooded (once every 8-10 years) and only for a short time (up to 0.5 months). These include the peaks and slopes of the highest ridges, as well as the surface of the remains of floodplain terraces with superimposed floodplains. The dominant position in the vegetation cover is occupied by floodplain forests - birch, aspen and pine-birch. Rosa acicularis, Padus avium, Viburnum opulus and Swida alba grow in their shrub tier. The grass cover is mosaic; in the lower areas it consists of motley-grassreed-grass, and in the more elevated areas it consists mainly of tall grass species: Filipendula ulmaria, Lysimachia vulgaris and Veronica longifolia. Of the mosses, Climacium dendroides is often found.

In the highest sections of the outliers and high ridges, mixed and coniferous grassy floodplain forests are found (which are closest to the zonal), mainly consisting of pine-birch 
and birch-pine and birch-silver-fir-spruce. Representatives of taiga small grasses and green mosses participate in their cover together with floodplain species.

A special complex of hydro- and hygrophilous plant species develops along the banks of small rivers. Here, the sedges, acute and beaked, are common, as well as swamp horsetail, marsh calla, marsh-marigold, creeping buttercup and other species.

In the course of the study, the locations of 7 species of plants listed in the Red Data Books of the Russian Federation [7] and the Tyumen region were recorded.

In 2016, for the first time for the southern part of the Tyumen region, Isoetes lacustris L. and I. echinospora Durieu were found in the southwestern part of a small intra-bog lake, located $15 \mathrm{~km}$ north of the Demianka station [8]. Both species are listed in the Red Data Book of the Russian Federation: I. lacustris possesses status 3 - a rare species, I. echinospora (under the name of I. setacea Durieu) possesses status 2 - a species that is declining in number. Based on the data obtained, both species are also included in the Red Data Book of the Tyumen Region, under category $4-$ a species with an undefined status. $I$. echinospora is found as solitary specimens and in small groups at a depth of 0.3 to $0.9 \mathrm{~m}$. Single specimens of I. lacustris were found together with I. echinospora. At a depth of $0.7-$ $1 \mathrm{~m}$, I. lacustris forms quite extensive dense thickets. The coastal-aquatic vegetation of the reservoir, consisting of submerged and floating hydrophytes, is practically undeveloped and is represented by small groups of Sparganium angustifolium Michx and Nuphar pumila (Timm.) DC. The latter species is also subject to regional protection (status 3 - a rare species). Based on the results of the survey, a proposal was prepared and presented at a meeting of the Commission on Rare and Endangered Species of the Tyumen Region to grant the lake the status of a specially protected natural area, and the subsoil user had decided to abandon the development of a quarry located in the immediate vicinity.

Also within the boundaries of plots reserved for search areas for quarrying on the right floodplain terrace of the river Irtysh opposite the village of Tugalovo, numerous (over 20) localities of Phegopteris connectilis (Michx.) Watt., Lobaria pulmonaria (L.) Hoffm. and Neckera pennata Hedw. have been found. Phegopteris connectilis was found in groups of up to several dozen specimens in communities of mixed dark-coniferous-small-leaved forests. The species is listed in the Red Data Book of the Tyumen Region, possessing status 3 - a rare species. Lobaria pulmonaria and Neckera pennata have been found on the trunks of old aspens, often growing together. Lobaria pulmonaria has also been found on the trunks of birches and rowans. The species is listed in the Red Data Book of the Russian Federation under category $2-$ a species that is declining in number. Both species are also listed in the Red Data Book of the Tyumen region. To preserve the habitats of these species, the layout of the sand quarries has been adjusted.

In 2018, within the projected boundaries of the quarry on the outlier in the floodplain of the river Irtysh $\left(59.7^{\circ} \mathrm{N}, 69.6^{\circ} \mathrm{E}\right)$, a single specimen of Dryopteris filix-mas (L.) Schott, listed in the Red Data Book of the Tyumen Region, possessing status 3, was found in the birch-small-grass-sedge forest - a rare species. At the moment, project work on this site is suspended. Considering the importance of the sand deposit for the further exploitation of the field, the possibility of transferring the discovered fern specimen to a similar habitat outside the boundaries of the projected quarry is being negotiated with the Department of Subsoil Use and Ecology of the Tyumen Region.

\section{References}

1. N.S. Drachyov, Flora of the subzone of the southern taiga within the Tyumen region. Dissertation of the Cand. of biological sciences (Novosibirsk, 2010) 
2. N.S. Drachyov, Biodiversity. Plant introduction: Proceedings of the IV International Scientific Conference (Saint-Petersburg, Komarov Botanical Institute RAS, 2007)

3. N.S. Drachyov, VI Zyryanov Readings: Materials of the Russian Scientific and Practical Conference (Kurgan, Publishing house of Kurgan state University, 2008)

4. N.S. Drachyov, I.V. Kuzmin, Environment and natural resource management. Abstracts of reports of the International Conference (Tyumen, 2010)

5. V. A. Glazunov, N. I. Naumenko, N. V. Khozyainova, Guide to Vascular Plants of the Tyumen Region (Tyumen, LLC "RG” prospect", 2017)

6. I.S. Ilyina, E.I. Lapshina, N.N. Lavrenko and oth., Plant Cover of the West Siberian Plain (Novosibirsk, Nauka, 1985)

7. Red Data Book of the Russian Federation (plants and mushrooms) (2008)

8. V. A. Glazunov, Bot. J., 2 (2018) 